\title{
DEL ALMANAQUE AL MAGAZÍN: \\ IRRUPCIÓN DE UNA NUEVA FORMA DE VER LA PRENSA EN CHILE $(1860-1905)^{1}$
}

\author{
POR \\ Marina Alvarado \\ Universidad Católica Silvia Henríquez
}

\section{INTRODUCCIÓN}

Diversos investigadores que se ocupan de la prensa latinoamericana del 1800, como Hernán Pas, Claudia Román, Sandra Szir, Carlos Ossandón, Eduardo Santa Cruz, Juan Poblete y Bernardo Subercaseaux, coinciden en que la incorporación de ilustraciones en los periódicos fue un fenómeno que se inició en el siglo XIX. Esto se debió al proceso de industrialización creciente, iniciado en Europa, que experimentaron técnicas otrora artesanales, como es el caso del grabado, el cual de ser xilográfico pasó a ser mayoritariamente litográfico; además, no solo se renovó esta área sino que también formó e incorporó a especialistas tanto en grabados como en dibujos. Muestra de lo anterior son los magazines londinenses y parisinos, el Penny Magazine (1830) y el Magasin Pittoresque (1833), respectivamente, los cuales atrajeron y conformaron un nuevo "público lector", ${ }^{2}$ caracterizado este último por buscar entretenimiento y a la vez conocimiento dispuesto de forma amena y precisa.

En la prensa chilena, la inclusión de grabados y caricaturas se puede ver desde 1842 en el periódico fundado por Juan Domingo Faustino Sarmiento, El Progreso, aunque de acuerdo a la información que aporta Bernardo Subercaseaux "la litografía fue introducida a Chile en 1820 por Lord T. Cochrane" (34). Sarmiento incorporó a sus folletines caricaturas que cumplían la función de acompañar y/o complementar el mensaje del texto principal. Esta novedosa inserción resulta totalmente coherente con el proyecto cultural, intelectual y educacional del argentino, por esos años, avecindado en

1 Este artículo forma parte de mi proyecto FONDECYT Regular 1140222 del cual soy Investigadora Responsable, titulado "La sección folletín de la prensa en Chile (1842-1900): inclusión, difusión y transformación de una sección que fue mucho más que novelas por entrega".

2 Esta idea de "público lector" la entendemos desde Roger Chartier, quien señala que "no hay práctica ni estructura que no sea producida por las representaciones, contradictorias y enfrentadas, por las cuales los individuos y los grupos den sentido al mundo que les es propio" (45). 
Chile, considerando que desde su llegada a Valparaíso apeló por el uso de un lenguaje idóneo al habla local para que los chilenos lo comprendiesen y así aumentara el número de alfabetizados, por ende, la civilización derrotara a la barbarie. ${ }^{3}$

Posterior a El Progreso, periódicos como El Correo Literario (1858) y El Cóndor (1863), entre los más destacados, levantaron sus respectivos proyectos periodísticos teniendo a la caricatura política (una de las categorías más populares y recurrentes dentro del panorama de ilustraciones en la prensa durante el siglo XIX) como eje, centro de atractivo y opción cierta para aumentar los suscriptores a las publicaciones. Por estas razones las ilustraciones eran bien anunciadas y descritas:

Ilustraciones de este número

Acompañamos a este número cinco pájinas [sic] de ilustraciones; una de ellas, es un efecto de luna en el desierto de Atacama tomado desde la bahía de Playa-brava [sic] [...] Cuatro caricaturas que representan cada una de ellas una idea $i$ con las que queremos manifestar a los susceptibles, que este jénero [sic] nuevo entre nosotros, solo puede inquietar a los lesos. (El Correo Literario, 1858, 12)

[...] No concluiremos sin avisar que EL CONDOR [sic] será ilustrado cada semana con una o dos caricaturas que sin herir, representen cuadros de la situación, trabajo, que, como se sabe, a mas de los gastos que orijina [sic] es por demás difícil i engorroso.Un jóven [sic] chileno, a quien no falta la chispa del arte, es el que ensayará su talento en esta tarea [...]. (El Cóndor, 1863)

Otro tipo de periódico de la época que también incorporó imágenes y que representa al formato periodístico que experimentó mayores transformaciones durante la segunda parte del siglo XIX debido al incipiente proceso de modernización de la prensa, el ascenso en Chile de los sucesivos gobiernos liberales, la paulatina laicización del Estado, la creciente burguesía y conformación de las capas medias y las nuevas leyes en torno a la imprenta, ${ }^{4}$ fue el almanaque. Peter Burke en su libro Visto y no visto (2005), explica que "las imágenes proporcionan prácticamente el único testimonio existente de prácticas sociales" (13), razón por la cual no es aconsejable continuar usándolas como medio para corroborar hipótesis de trabajo pre establecidas, sino que debemos dejar "hablar" a las imágenes para permitirnos ver qué es lo que estas desean contarnos

\footnotetext{
3 Sobre esto, Álvaro Fernández Bravo indica que, "[...] al abogar a favor de una lengua escrita que reflejara con mayor fidelidad el habla popular de los chilenos, Sarmiento no solo desafiaba el apego a la norma peninsular recomendada por el intelectual caraqueño [Andrés Bello] sino que consideraba este un gesto necesario para la independencia cultural" (143).

4 La Ley de Imprenta, según explica Eduardo Santa Cruz, correspondió “[a]1 nuevo marco legislativo instalado a partir de la normativa promulgada en 1872, le permitió un notable desarrollo y especialmente que comenzará a cambiar radicalmente su carácter. En estas décadas comienza a configurarse el periodismo liberal moderno, el cual tiene como expresión orgánica, la empresa periodística [...]" (4).
}

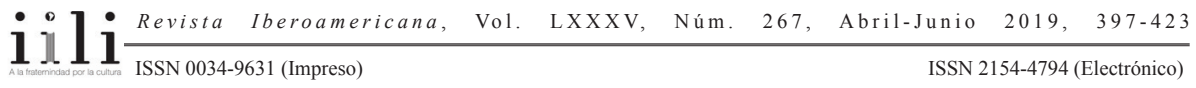


sobre la historia cultural. De acuerdo con esta premisa y propuesta metodológica de estudio, es que revisando distintos almanaques chilenos de la segunda mitad del XIX, nos encontramos con ilustraciones que acompañaban a los escritos allí expuestos; algunas de menor calidad y otras muchísimo mejores (por sus dibujos más acabados y ser representaciones naturalistas) y además firmadas por sus creadores, pero al fin y al cabo todas ellas imágenes que pretendían amenizar la lectura. Para el caso de los grabados firmados, indagamos el origen de sus autores, encontrándonos con que estos eran franceses reconocidos por su participación en revistas magazine parisinos. Estos hallazgos son los que motivan y dan origen a este artículo.

El propósito de este trabajo es reconocer, primero, la irrupción que tuvo en la prensa chilena el formato magazinesco gracias a la apropiación que de dicho estilo de periodismo experimentaron los almanaques seculares de la segunda mitad del siglo XIX $\mathrm{y}$, en segundo lugar, los ecos que tuvieron las "formas" propias del almanaque en el magazine, principalmente en Zig-Zag. Esta constatación la realizamos a partir del estudio de las imágenes de los almanaques y de sus contenidos, lo cual nos permite afirmar que hay un cambio importante en la noción de ilustración, palabra que se resemantiza, pues ya no se entiende únicamente como la corriente intelectual-estética, sino que a partir de ese momento aludiría a la presencia de imágenes (grabados y dibujos).

Los tres supuestos que buscamos corroborar en este trabajo son los siguientes: primero, los almanaques chilenos son un antecedente relevante para reconocer el modo en que se incluyeron en Chile los magazines, ya que importaron el formato desde Francia, país cuna de este tipo de prensa. En segundo lugar, la cultura del (h)ojeo en Chile no comenzó exclusivamente de la mano de los periódicos ilustrados del siglo XIX (diarios y revistas), sino que fueron los almanaques los que la promovieron con mayor claridad, al igual que la diversificación y laicización de los contenidos. Tercero y final, los magazines en Chile, especialmente Zig-Zag, debido a su proyecto editorial orientado hacia la élite ilustrada y emergente, ${ }^{5}$ tomaron elementos de los almanaques para cubrir los servicios informativos que ese tipo de publicación proporcionaba al público lector en el siglo XIX, pues intentaron ser periódicos útiles y abarcadores, al punto que su organización y los temas que allí aparecían dependían de la festividad celebrada o conmemorada, por lo que podríamos presuponer que el magazín funcionó como un almanaque anual-mensual-quincenal.

La estructura de este artículo considera tres apartados. El primero de ellos llamado "Panorama de almanaques y magazines en Chile", revisa el proceso de inserción y publicación en la prensa chilena de almanaques y magazines, desde 1850 hasta 1910 , con el propósito de situar el surgimiento y modalidades de ambos tipos de periódicos.

Otros magazines importantes en la época fueron Sucesos (orientado hacia los sectores medios), Pacífico Magazine (dirigido a la élite aristocrática; además estaba sumamente basado en la prensa y estilos neoyorquinos) y Corre Vuela (pensado para ser leído por el público popular).

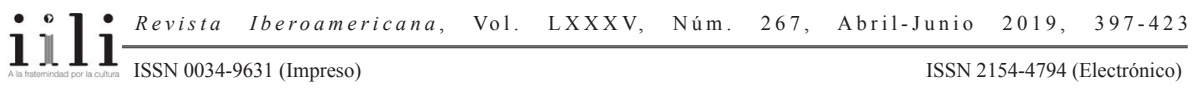


En la presentación y análisis de cada periódico se hace hincapié en los propósitos que plantearon ante el público y la "puesta en escena" de ellos. El segundo se titula "Inclusiones, continuidades y funciones compartidas", en donde se analizan almanaques en diálogo con el género magazine francés en el cual se habría basado; aquí nos detenemos en las imágenes tanto de los textos que acompaña como de la publicidad. Mismo análisis hacemos del magazine Zig-Zag, del cual extraemos las "huellas" de almanaque y la absorción de dicho formato.

\section{Panorama de almanaques y magazines en Chile}

Los almanaques son las publicaciones de la segunda mitad del siglo XIX que testifican el proceso de secularización que comenzó a experimentarse tanto en la sociedad chilena de la época como en los medios de comunicación escritos. Juan Poblete habla del desencantamiento del mundo, donde se evidencia el tránsito desde la ciudad patricia hacia la ciudad burguesa, tema que por cierto se transformaría en eje temático de las novelas de la época, incluyendo a Alberto Blest Gana y Rosario Orrego, ${ }^{6}$ por mencionar a los más destacados. Por lo tanto, los almanaques no son nuevos para el período, pero lo novedoso es su transformación "tanto gráfica como semántica, las formas de su comercialización y el tipo de lectores implícitos en dicha renovación" (Poblete 100).

La aparición de almanaques en Chile data, al menos basándonos en los documentos que se resguardan en la Biblioteca Nacional de Santiago de Chile, desde 1815, donde encontramos el Almanako Calendario y diarios de cuartos de luna según el meridiado de Santiago de Chile para el año 1815. En 1825, nos encontramos con el Almanak u ordenación del año 1825. Décimo sexto de nuestra libertad. De acuerdo a lo que expone Poblete, este último almanaque presenta variaciones significativas, no sólo desde la perspectiva gráfica y temática, sino también en las estrategias discursivas que utiliza, ya que establece de modo cierto la Independencia del país a partir de 1810. No por ello se descuida la inclusión de las materias tradicionales de estas publicaciones, como el santoral, fechas de festejo católicas, nombres de los gobernantes de turno y pronósticos meteorológicos, en muchos casos.

El Almanaque Pintoresco e Instructivo para el año 1851, materializado por la imprenta de Julio Belin y Compañía, destaca por las ilustraciones que acompañan a los textos, las cuales tienen la función de ejemplificar de modo gráfico aquello sobre lo cual se expone. A lo anterior se suma un elemento novedoso y que no viene más que a acentuar el espacio común que de ahora en adelante deberían compartir asuntos

6 De estos escritores consideramos sus novelas Martín Rivas (1862), de Blest Gana y Alberto el jugador (1860), de Orrego.

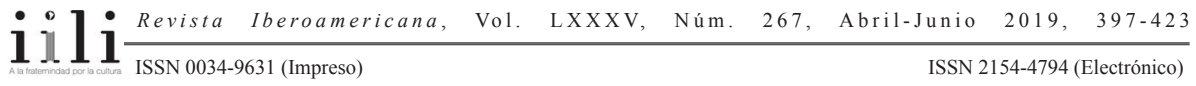


religiosos con otros ligados al paganismo. Nos referimos a la incorporación de los signos del zodiaco al costado de cada mes en el que se supone corresponde la conmemoración de dicho signo. Según se observa en la figura 1 , al costado de enero está el símbolo que representa a acuario, y bajo esta información,

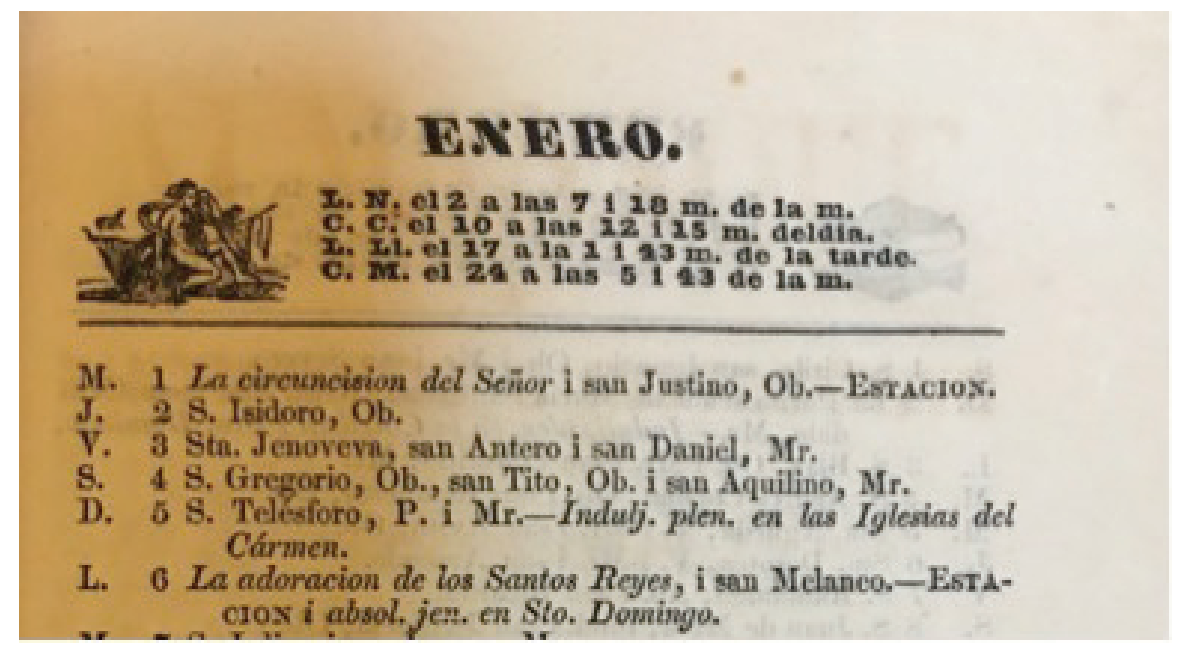

Fig. 1: Almanaque Pintoresco e Instructivo, 1851.

El Almanaque Pintoresco e Instructivo para el año 1852, por su parte, de la misma imprenta, continúa el modelo del año 51 aunque aumentó considerablemente el número de ilustraciones. Vale señalar que se mantiene la incorporación del zodiaco junto a otras informaciones tanto religiosas (fiestas católicas) como gubernamentales (reuniones del congreso), textos literarios y otras de utilidad pública (frecuencia de los trenes).

El Almanaque chileno del año 1855, manifiesta cambios respecto de las tradicionales publicaciones, situación que señala Juan Poblete, pues "se aprecia así el progresivo avance de una lógica de la gubernamentalidad civil" (104). Esta afirmación se refiere a cómo este almanaque toma el pulso a la complejización en la organización del espacio civil de la ciudad y del país. Pero por otra parte, el ingreso y la instalación de estos temas en una publicación tradicionalmente eclesiástica, demuestra que la pugna entre institucionalidad religiosa e institucionalidad gubernamental está siendo vencida por esta última. Muestra de esto es su portada, la cual es, ante todo, extremadamente patriótica y también pagana, según se observa en la figura 2.

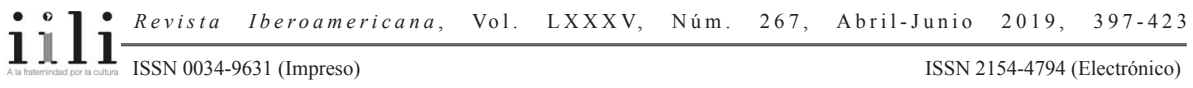




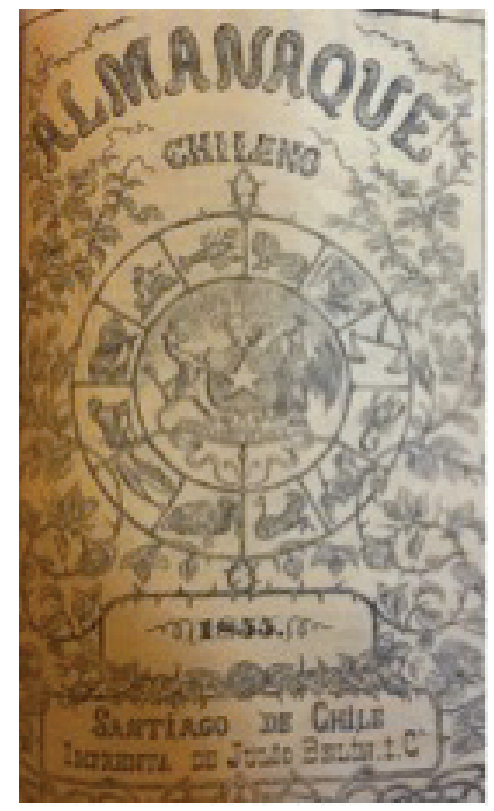

Fig. 2: Almanaque chileno, 1855, portada. Nótese que alrededor del escudo de Chile están las ilustraciones que representan a los 12 signos del zodiaco.

Los almanaques, Almanaque popular e instructivo para el año 1857, el Almanaque arreglado según el calendario romano. Con apuntes útiles para todos los individuos i clases de la sociedad, para el año de 1862 por N.O.N.; el Almanaque del curioso cristiano para el año de gracia de 1865 revisado por la autoridad eclesiástica y el Almanaque chileno para el año 1875 publicado por Nicasio Ezquerra, entre otros, demuestran, más bien, redemarcan los usos y el público hacia el cual van dirigidos. Es por lo anterior que los almanaques hacen eco de las necesidades cotidianas de los lectores, a quienes no solo les interesa conocer cuándo se celebra Semana Santa o cuál es el santoral del día, o simplemente cuándo se producen los cambios de estaciones, sino que también buscan en el almanaque información útil para la vida diaria. De allí que, similar a la guía de teléfonos que conocemos en la actualidad, nos encontremos con un apartado completo dedicado a la información y contacto de profesionales de diferentes áreas. Sin embargo, estas publicaciones empezaron a incluir acápites exclusivos para el goce y la entretención, donde se encontraba también a la sección literaria.

Caso paradigmático de la hibridación entre placer, servicio y buen gusto fue el Almanaque Enciclopédico Pintoresco de 1860, publicado y vendido por Santos Tornero. Este almanaque no solo reunía las características y secciones ya mencionadas y reiteradas

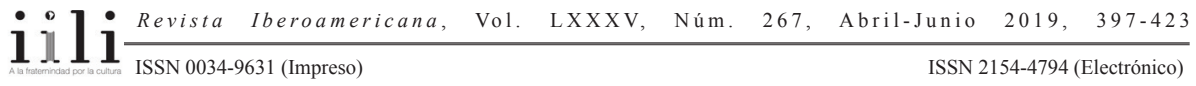


respecto de los demás textos, sino que marcó un verdadero cambio y sofisticación, ya que los dibujos y grabados aquí aparecidos pertenecían a artistas franceses, famosos por su participación en magazines parisinos, como es el caso de H. Pottin, FrancoisAuguste Trichon, ${ }^{7}$ E. Forest, A. de Bar, entre los más recurrentes. La calidad de los grabados, la disposición, los textos, incluso la publicidad, nos permite afirmar que este fue el almanaque más magazinesco de todos los revisados, inclusive de los posteriores al sesenta, pues tomando adoptó y adaptó el modelo periódico europeo a los nuevos gustos locales (véase la figura 3). De acuerdo con las cualidades encontradas, reconocemos que esta publicación tuvo como punto de referencia a Journal pour tous surgido en 1858 , en donde se desempeñaban los artistas antes señalados, especialmente Trichon (véase la figura 4).

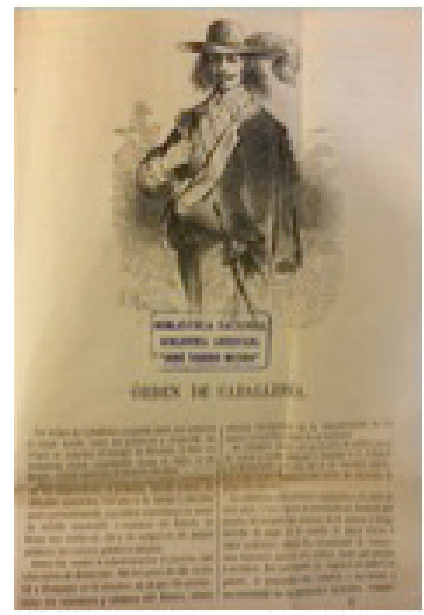

Figura 3: "Orden de Caballería" Almanaque Enciclopédico Pintoresco, 1860.

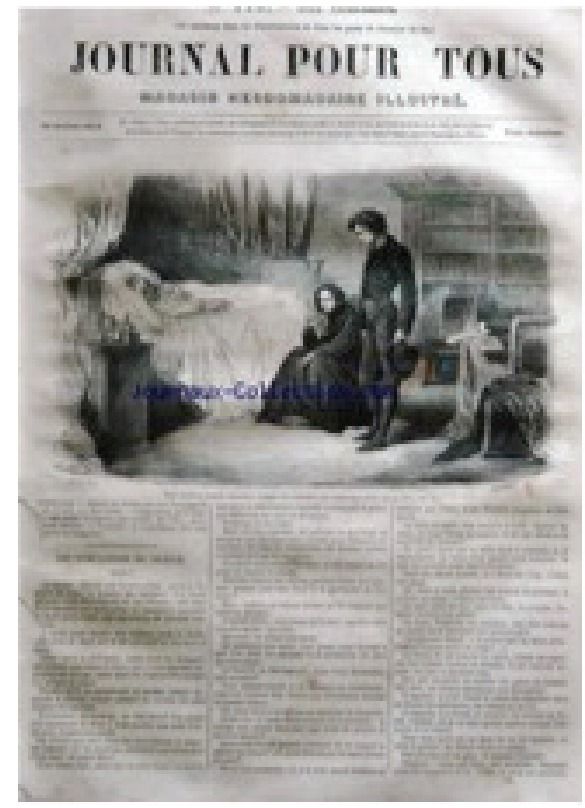

Figura 4: Portada, Journal por tous, 11 de julio de 1857.

7 Francois-Auguste Trichon (1814-1898) es el grabador más importante dentro del grupo de artistas indicados, pues él formó una verdadera escuela de grabadores sobre madera, tanto así que interesados españoles viajaban a Francia para aprender este oficio.

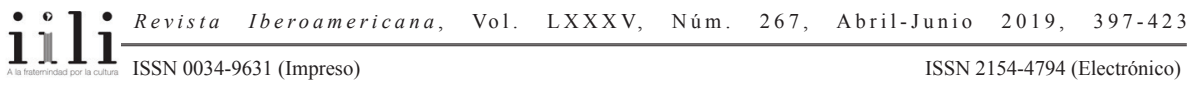


La década de 1870 está marcada por el ascenso de los sectores liberales al gobierno, otorgándoles hegemonía política, cultural, económica y social. En el año 1871 iniciaron los gobiernos liberales, siendo Federico Errázuriz Zañartu el primero de ellos. Las propuestas de los liberales y las reformas constitucionales realizadas con el fin de fortalecer la potestad del congreso en detrimento del ejecutivo, apuntaban hacia la ampliación formal y legal de las libertades públicas, y es en la prensa donde se permea con mayor claridad esta nueva disposición, gracias a la Ley de Imprenta de 1872. De allí entonces que en las últimas tres décadas del siglo XIX se evidenciara una estructura política, social y cultural que demostraba la plena instauración del capitalismo.

Frente a los cambios desarrollados, los almanaques no quedaron fuera de la “capitalización" de la sociedad, razón por la que tanto el Almanaque Divertido (1879) como el Almanaque Pintoresco (1880) expusieron en sus páginas avisos publicitarios que iban más allá del avisaje profesional, ahora serán páginas completas dedicadas a promocionar tal o cual librería, restaurante, botica, etc. Pero no es el producto lo interesante sino el lenguaje publicitario propiamente, como es el caso de las siguientes dos páginas del almanaque de 1879 :

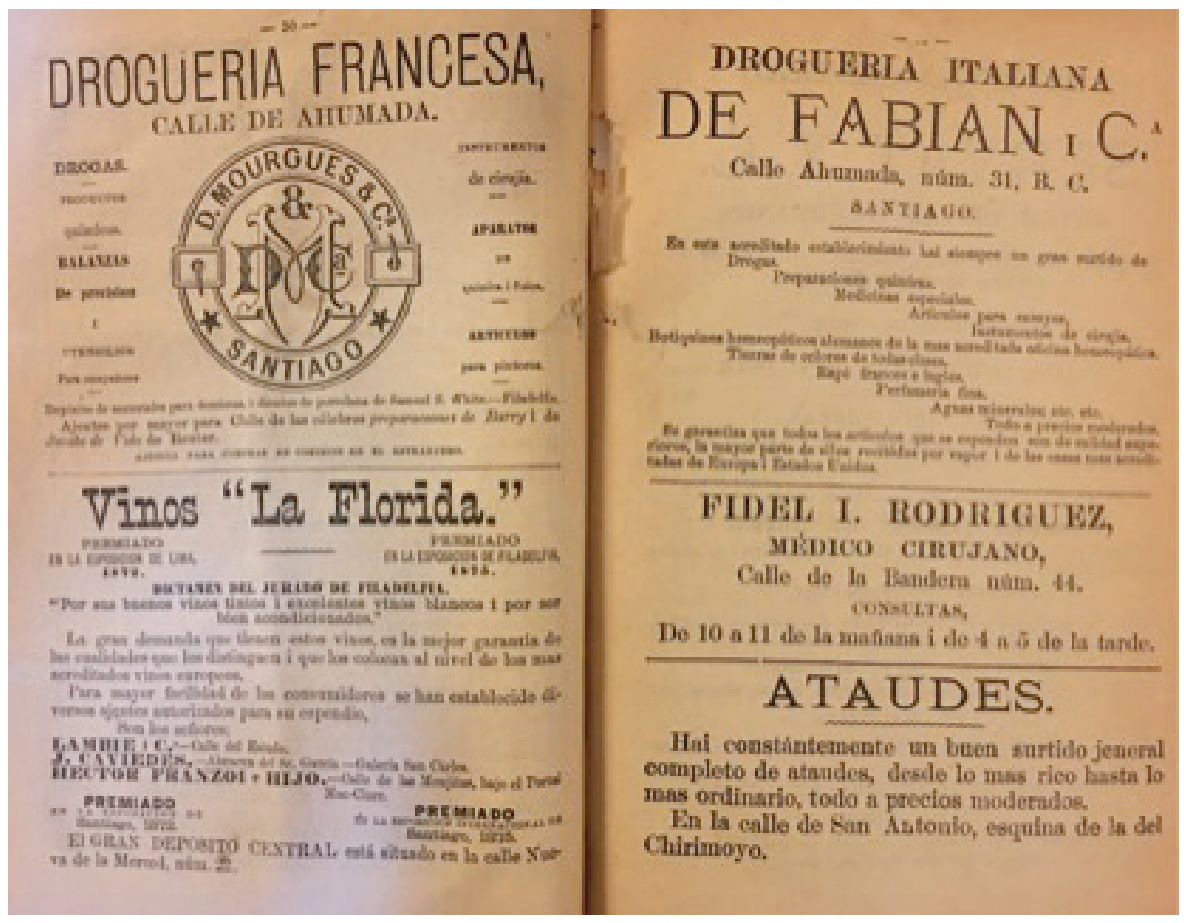

Figura 5: Almanaque Divertido, 1879, 30-31.

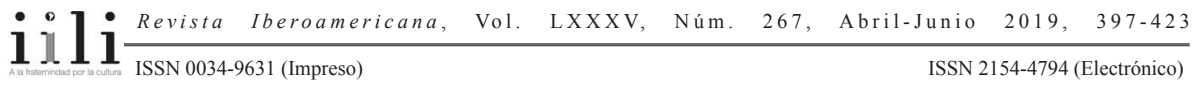


El Almanaque Divertido, desde donde extrajimos la imagen de la figura 6, era publicado por Jacinto Núñez desde el año 1864. Núñez no era nuevo dentro del ámbito periodístico-literario, pues en 1860 había publicado junto a Manuel Blanco Cuartín El Mosaico, publicación que Carlos Ossandón caracteriza como parte del nuevo entramado de la "prensa raciocinante", la que expresa una nueva economía del discurso periodístico por su autonomía de otros poderes de la esfera social, pero no por ello descomprometida de cuestiones políticas. Además, es importante mencionar que Jacinto Nuñez era propietario de la Imprenta de la República, ubicada en Santiago, en la calle del Chirimoyo número 30; por lo que, como es previsible, utiliza la plataforma del almanaque para promocionar las publicaciones y los servicios que su imprenta presta.

De manera similar al Correo Literario, el almanaque de Núñez también recurrió a caricaturas mordaces. Es el caso de la portada de la publicación de 1879 (figura 6). La portada de este almanaque juega con las siguientes imágenes. En primer lugar, tenemos al almanaque como un observador de lo que está aconteciendo, de allí que el hombre que, o bien podría ser Núñez o el mismísimo almanaque-personaje, está de pie sobre zancos y con un catalejo en la mano observando lo que le sucede a los "pequeños" hombres. Por otra parte, más que ser zancos sobre los cuales el hombrecillo está de pie, se trata de un compás utilizado en las cartas de navegación para medir latitud y longitud entre dos puntos distantes. A partir de lo anterior, entendemos que el almanaque se plantea no solo como un observador pasivo de lo que sucede, sino que como evaluador de lo que está sucediendo, capaz de anticipar lo que se suscitará en el año que comienza.

Respecto a la información que este almanaque entrega, se cuentan épocas célebres, aniversarios cívicos americanos, cómputo eclesiástico, fiestas movibles, las cuatro témporas, las cuatro estaciones y eclipses en 1879. En tres cuartos de página se revisan las efemérides chilenas del mes de enero. Así también se encuentra la "Guía general”, que entrega datos importantes para todos, especialmente, sobre gobierno, poder legislativo, de las elecciones directas, poder ejecutivo, consejo de estado, comisión conservadora y poder judicial. Pero no es hasta la página sesenta y siete de este almanaque donde se lee lo siguiente, "Parte recreativa, Lectura para todos los gustos. Cuentos, romances, pensamientos, epigramas, charadas, cantares, anécdotas, etc., etc.”( $\mathrm{s} / \mathrm{d}$ ). En esta sección se ubican los textos poéticos satíricos, que hacen referencia a los "estilos" sociales. ${ }^{8}$

La exposición de la crítica social a través de textos poéticos responde a lo que Poblete también advierte sobre el "proceso de literaturización", una de las formas en que los almanaques comenzaron a especializarse, a singularizarse y apuntar hacia un público específico. Debido a lo anterior, los almanaques revisados son ciertamente

8 Un ejemplo de esto es el siguiente texto titulado "Química social: Para hacer académicos": un sillón de terciopelo/ tomarás; /media vara sobre el suelo/lo pondrás;/ un señor mui estirado/en la silla sentarás,/ i tendrás / un injenio tan menguado.../Como todos los demás” (72).

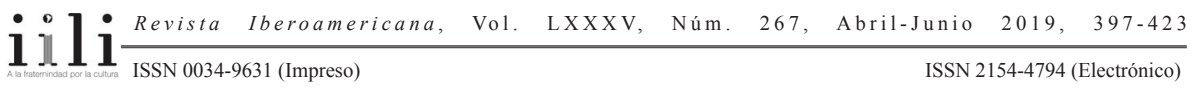




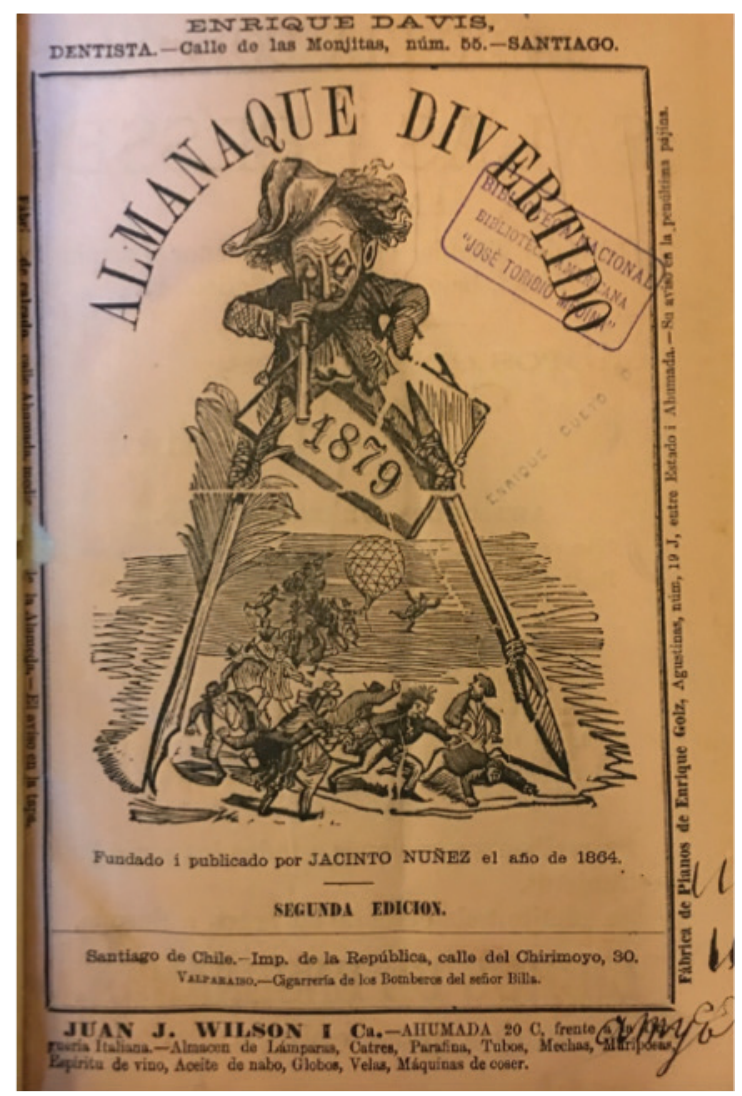

Figura 6: Almanaque Divertido, 1879.

antecedentes clave para identificar las primeras manifestaciones de profesionalización y legitimación de la práctica literaria, situación que se observa no solo en la aparición de secciones exclusivamente dedicadas a las letras, sino también en los avisos publicitarios que más abundan sobre librerías e imprentas.

En esta misma línea, nos encontramos con Carlos Segundo Lathrop, quien publicó en 1880 el Almanaque Pintoresco-Divertido, el que para ese año ya correspondía a su quinta versión. Lathrop, al igual que Núñez, no era nuevo dentro del incipiente campo literario nacional, pues en el año 1897 publicó la novela Sara Bell, o, Una víctima de la aristocracia: novela histórica nacional y en el año 1879 el texto dramático Tarapacá. Es decir, la producción literaria de este escritor es moderna, considerando además que el nombre que lo hizo reconocido corresponde a un seudónimo, pues su nombre original es Oscar Hall-Port. Junto con lo anterior, no podemos dejar de mencionar que Carlos

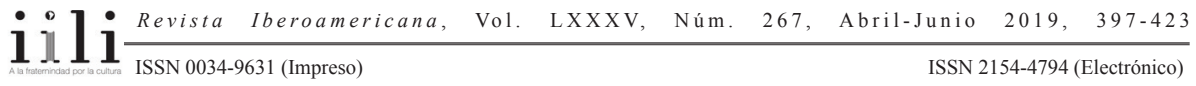


Segundo era propietario de la Librería Americana de Carlos $2^{\circ}$ Lathrop, ubicada en el número 35-B de la Calle Ahumada; por lo tanto, las páginas del almanaque son la plataforma ideal para promocionar dicho establecimiento.

A partir de lo revisado, creemos que tanto Jacinto Núñez como Carlos Lathrop son los primeros gestores culturales y literarios del siglo XIX, ya que, no solo se dedicaron a escribir textos literarios, sino también a generar instancias de reconocimiento y divulgación tanto de la labor personal como de la esfera literaria completa. Este es el caso de la particular preocupación del Almanaque Pintoresco-Divertido por dedicar un artículo completo a la conmemoración de la fundación de la Sociedad de Bibliotecas Públicas Escolares, ocurrida el 19 de marzo de 1878. En cuanto a la estructura del Almanaque Pintoresco-Divertido, este contiene fechas históricas y religiosas, cómputo eclesiástico y fiestas movibles. Se señalan también, las cuatro estaciones y los eclipses. Además, para cada mes se indican fechas importantes y efemérides de la iglesia católica. A diferencia del Almanaque Divertido, esta publicación entrega mayor espacio a la producción literaria de sus colaboradores, donde se cuenta a Robustiano Vera, Víctor Torres, Domingo Arteaga Alemparte, Rosendo Carrasco, Hortensia Bustamente de Baeza, Parlero, Santiago Escuti Orrego, Manuel Hurtado y el mismo Carlos Lathrop. Uno de los apartados que destaca dentro de la extensa sección literaria del almanaque es la llamada "Retratos", donde encontramos textos poéticos de crítica social, pero que además, por medio de ellos, es posible comprender el posicionamiento de esta publicación respecto de los otros agentes literario-políticos de la época. Podemos considerar, además, que esta parte hace las veces de programa editorial del mismo, a la vez que declaración de principios diferenciadores de otros almanaques y publicaciones como periódicos y revistas.

Intentar satisfacer la demanda de los lectores, incorporando nuevos avances tecnológicos en el diseño e impresión de las revistas, es la clara señal que nos permite reconocer el nacimiento de la industria cultural moderna, de la mano del magazine, expresado total o parcialmente por Pluma y Lápiz (1900), La Lira Chilena (1898), La Ilustración (1899), Luz y Sombra (1900), Instantáneas (1900), Instantáneas de Luz y Sombra (1900) y La Juventud (1901). Pese a adoptar parcialmente el formato magazinesco, ${ }^{9}$ se dedicaron exclusivamente a temas artísticos, literarios y culturales, generándoles un capital específico interesante que les permitió diferenciarse de las demás manifestaciones escritas de la prensa del período, pero al mismo tiempo su

9 El magazín es definido convencionalmente como, un periódico ilustrado [...] se trata de un género que es capaz de albergar en su interior en forma entremezclada crónicas, entrevistas, reportajes de actualidad, ilustraciones, avisos publicitarios, cuentos y novelas por entrega, notas de vida social, caricaturas, poemas, etc. En este sentido, se trata de un género extraordinariamente maleable en cuanto a sus formatos y contenidos (Ossandón y Santa Cruz 33).

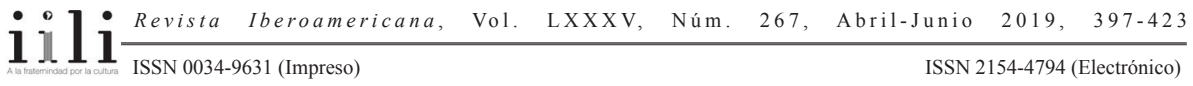


público continuaba siendo reducido, pues apuntaron a lectores más especializados y no a uno masivo, pese al dinamismo y a las nuevas gráficas incorporadas.

El Mercurio de Santiago supo aprovechar el cuerpo intelectual forjado al alero de los periódicos literarios de fines del 1800, agrupándolos en sus salas de redacción y sus columnas. Pero paraAgustín Edwards Mac Clure el tabloide no era suficiente y creyó que este necesitaba de un suplemento, aunque El Mercurio ya tenía bastante audiencia y se valía por sí mismo. De allí que en 1904, fecha en que Edwards comenzó a proyectar lo que posteriormente sería Zig-Zag, partió a Estados Unidos en busca de ideas, maquinarias y personal de las mismas Underwood para capacitar a los trabajadores chilenos y así, hacer llegar al público una revista de calidad nunca antes vista. Desembarcaron en Chile las máquinas más modernas y un taller completo de fotograbado, con el cual se materializarían las ilustraciones en negro y en colores. Además, Edwards contrató a un técnico especialista en asuntos de grabados de colores, especialista en el sistema de impresión conocido como "tricomía" o grabado en tres tintas. Esta gran inversión resultaba inédita para la época, pues Agustín Edwards era concsiente de que, a diferencia de otras transacciones económicas, los resultados y beneficios pecuniarios no serían inmediatos, sino que a largo plazo; es decir, el "pasando y pasando" no era parte de las intenciones inmediatas de este negocio. Pero involucrarse en este tipo de proyecto no solo respondía a una "tincada" personal, sino que los factores de la época indicaban que una empresa como esta sería bien recibida. Sobre esto, Félix López en el número conmemorativo de los cincuenta años de Zig-Zag comentó lo siguiente,

[...] el ambiente editorial estaba ya preparado por entonces para publicaciones de una mayor pretensión, con vistas a abarcar públicos más vastos, aunque en ellas fuera sólo una parte la expresión netamente literaria, dejando para el resto la nota periodística y de actualidad de los acontecimientos de la vida nacional y extranjera. (Medio Siglo de Zig-Zag, 1955, 65)

López, en párrafos posteriores, menciona la importancia de la "culturización" de la clase media, la cual gracias a las políticas educativas e intervenciones sobre la instrucción primaria forjadas por Manuel Balmaceda habían sido posibles. De allí que en la cita se destaque la presencia de revistas especializadas desde fines del siglo XIX, con las cuales se comenzó a allanar el camino, tanto para lectores, productores como para las mismas revistas. En este sentido, la multiplicación de medios escritos respondió, principalmente, a la necesidad por publicitar y abordar a través de un soporte material las nuevas organizaciones discursivas y representaciones enunciativas que estaban emergiendo.

A partir de los antecedentes respecto de la disposición del mercado editorial y habiendo visto el caso de Sucesos fundada en 1902, el magazín de los hermanos Gustavo

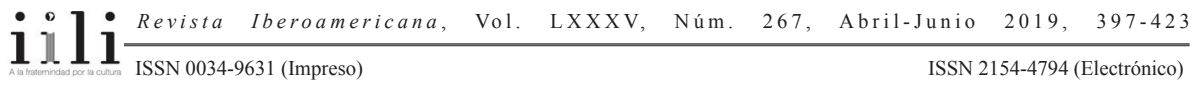


y Alberto Helfmann editado en Valparaíso, ${ }^{10}$ el día 19 de febrero de 1905 apareció el primer número de Zig-Zag, precedida de un despliegue publicitario novedoso para el caso de una revista. A esto se refiere Fernando Santiván, quien recuerda que,

el revuelo que produjo el solo anuncio de la fundación de Zig Zag fue enorme. Chile entero apareció empapelado con un gran cartel en colores que decía 'Compre Ud. Zig Zag', 'Lea Ud. Zig Zag', 'Próximamente aparecerá Zig Zag', y otras frases por el estilo. La prensa local se encargó de dar cuenta de los menores pasos de la proyectada revista [...] Quizás ninguna empresa periodística, hasta entonces, se había iniciado con tal magnificencia y costo. Apareció, por fin. Los 100.000 ejemplares del primer número se agotaron en pocas horas.

(Citado en Santa Cruz 50)

La estrategia publicitaria iniciada por Zig-Zag fue eficiente y apoteósica, como para ubicarse por sí misma dentro del entramado periodístico-cultural. Sin embargo, la portada del número uno del magazín de Edwards también es bastante significativa (véase la figura 7), pues se observa a Mercurio entregando a una recién nacida desde su huevo, a Zig- Zag, como si se tratase de su padre. Es decir, el capital simbólico de El Mercurio es traspasado a la revista; y no sólo eso, sino también los agentes que participaban del periódico, los auspiciadores y los mismos lectores. Podríamos decir entonces, que el magazine inició sus publicaciones con gran ventaja respecto de las demás revistas gracias al capital heredado de la cual fue beneficiaria.

En otro aspecto, Zig-Zag absorbió a los escritores ya consagrados. Sucesivo a ello, las revistas de propiedad de escritores y no de editoriales que venían desde los últimos años del siglo XIX desaparecieron. Sobre esto, creemos que Zig-Zag y los demás periódicos publicados bajo la misma casa editorial, buscaron reorganizar la serie de relatos culturales que se estaban produciendo en ese momento en el país, intentando constituirse, en sí mismas, en una propuesta que abarcara y unificara la mayor cantidad de públicos lectores y que ordenara a la "masa lectora" que estaba disgregada, inquieta por exponer sus propios discursos y leerlos al mismo tiempo. Es

${ }_{10}$ Pese a la serie de innovaciones tecnológicas que Edwards importó para producir Zig Zag, requirió de los servicios de los talleres Universo, propiedad de Gustavo Helfmann y Gustavo Ross Santa María, quienes a partir del primero de febrero de 1905 iniciaron las operaciones como sociedad anónima UNIVERSO (Sociedad Imprenta y Litografía Universo). Pero no fue hasta 1912 cuando Agustín Edwards Mac Clure y Gustavo Helfmann decidieron asociarse y fusionar Zig-Zag editorial con Universo. La mezcla entre la experiencia revistera de Edwards y la de Helfmann en la imprenta fue la alianza perfecta para potenciar la revista Zig-Zag, proyectar nuevas publicaciones, y dar inicio a la edición de libros nacionales bajo la editorial Zig-Zag. En el año 1934, después de la gran depresión del año 29, Helfmann terminó por reorganizar Zig-Zag, dando paso a la Empresa Editora Zig-Zag S.A., y desde su cargo de Presidente del Directorio, asumió la dirección de esta, modernizando talleres y ampliando el número de publicaciones.

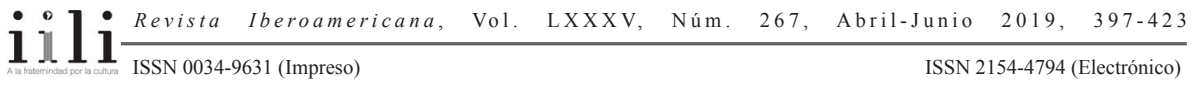




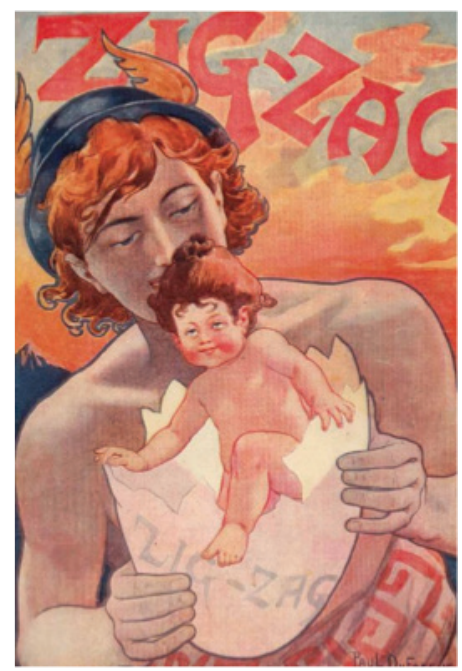

Figura 7: En referencia a la metafórica imagen de la portada del primer número del magazín, ésta última es representada por una bebé. El género de la recién nacida no nos parece casual, y va más allá que el género del sustantivo "revista" sea femenino. Creemos que esto tiene que ver con el género de los y las lectores y lectoras a los cuales va dirigida esta publicación o por quienes iba a ser mayormente preferida. La lectura de periódicos era concebida como una práctica viril, así también la producción de los mismos. En contraste con esas publicaciones, las revistas quedaban en un lugar menos aventajado, al igual que las mujeres, por ende, se les caracteriza como un acompañamiento del periódico cuyos temas eran más bien para la entretención y no para informarse sobre asuntos medulares como la política y la economía.

decir, postulamos que las revistas de Edwards fueron la respuesta discursiva burguesa frente a la heterogeneidad sígnica y enunciativa predominante en el período final del siglo XIX e inicios del siglo XX.

\section{INCLUSIONES, CONTINUIDADES Y FUNCIONES COMPARTIDAS}

Eduardo Santa Cruz explica que los magazines cumplieron las siguientes funciones: vulgarizar el conocimiento y las novedades tecnológicas, difundir la modernización y el progreso, distribuir publicidad y, finalmente, expandir el imaginario colectivo y el sentido común. Los almanaques de los cuales nos hacemos cargo en este trabajo, puntualmente los posteriores a 1850, hicieron eco de estas mismas funciones; sin embargo, el análisis no es productivo si revisamos en qué medida dichos periódicos cumplieron o no con ellas, pues consideramos que el valor de sistematizar la crítica de los almanaques a la luz de esas categorías radica en distinguir el sentido que en el siglo XIX y en Chile tuvo apropiarse de esas cualidades. 
El Almanaque Pintoresco e Instructivo para el año 1851 mostró en sus páginas las nuevas tecnologías al servicio del transporte público. Para ello, en un artículo proyectivo y un tanto "futurista" señaló los beneficios que tendría en Chile contar con una "locomitiva" (verifiquen figura 8). En el texto que acompaña a la ilustración se explica cómo funciona esta máquina, pero, según allí mismo indican, "sería largo entrar en detalle sobre el mecanismo de la locomitiva" (33). Por esta razón, en vez de especificar con tecnicismos los usos de la "locomitiva", se concentran en explicar que hacia el 1851, en Chile se debieran construir más kilómetros de líneas de hierro, por lo cual las distancias entre algunas ciudades, especialmente las del norte, se acortarían. En definitiva, en el almanaque se recurre permanentemente a hablar de aquello que será o debiera ser, pensando en un futuro próximo, lo cual está en línea con el discurso sobre el progreso propio del siglo XIX.

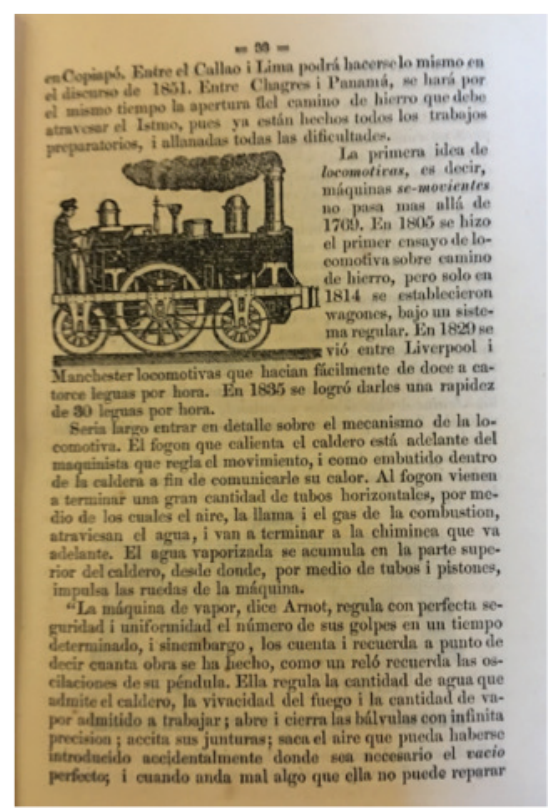

Figura 8: Almanaque Pintoresco e Instructivo 1851.

La arquitectura, en tanto rasgo propio de la modernización y los adelantos, especialmente la urbanización de la ciudad, tampoco quedó exenta de los asuntos abordados en 1852 por el Almanaque Pintoresco e Instructivo. Es en este tipo de artículos en donde con mayor notoriedad queda clara la intención del siglo XIX en

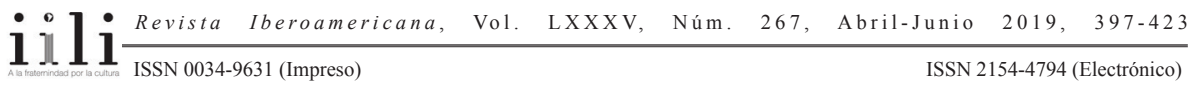


Chile por eliminar todo aquello que recordase al reciente pasado colonial, por lo cual la construcción y diseño de edificios, es decir la capa visible de la ciudad, es quien debe modernizarse y experimentar los cambios. Al igual que lo ocurrido con el ejemplo anterior de la "locomitiva", el artículo habla en futuro, sobre cómo debería quedar la ciudad luego de las transformaciones:

Los progresos que Chile hace en las ideas i [sic] en el desarrollo de su riqueza debían representarse en signos materiales por medio de un cambio en la materia, forma $\mathrm{i}$ [sic] distribución de los edificios [...] La arquitectura colonial i [sic] sus progresos posteriores pudieran reducirse a órdenes $[\ldots](45)$

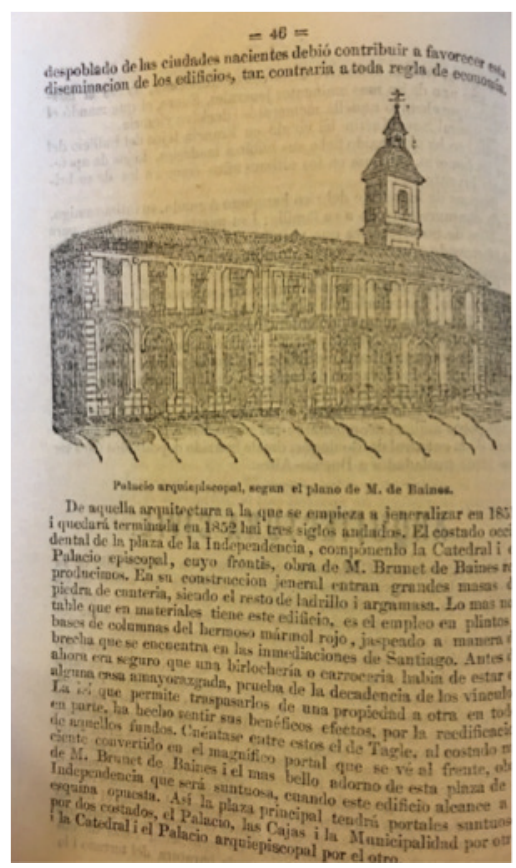

Figura 9: "Arquitectura Civil", Almanaque Pintoresco e Instructivo, 1852. La imagen central corresponde al Palacio arquiepiscopal, según el plano de M. Baines. Es decir, se recurre nuevamente a la ilustración para demostrar cómo va a quedar dicho edificio luego de los cambios que se realicen.

La búsqueda por reflejarse en parámetros estéticos y culturales distintos de los heredados por España es otro de los elementos recurrentes en los almanaques, especialmente en el Enciclopédico Pintoresco de 1860, el cual, como ya anunciáramos antes, fue el más magazinesco y afrancesado de todos estos periódicos debido a que sus

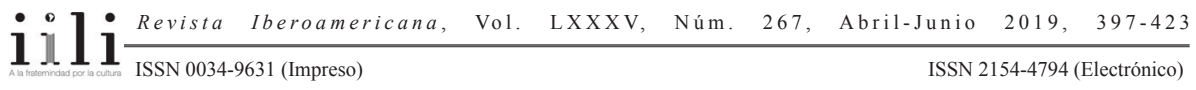


grabados (como el que observamos en la figura 10), pertenecen a artistas franceses. ${ }^{11}$ Para el caso de este periódico y del ejemplo en particular que exponemos, este se preocupó de funcionar como una verdadera ventana hacia el mundo, presentando un imaginario estilizado de acuerdo con la perspectiva francesa.

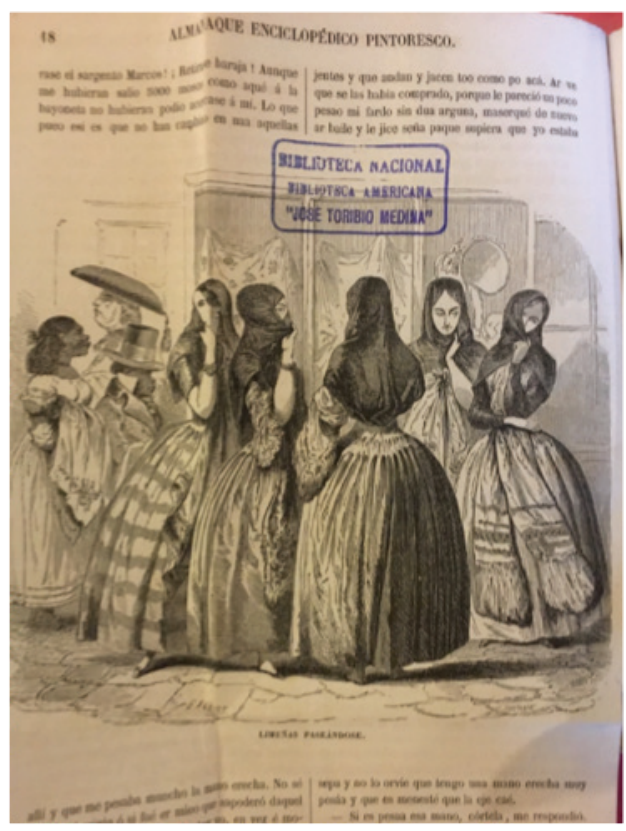

Figura 10: "Limeña paseándose” Almanaque Enciclopédico Pintoresco, 1860.

La publicidad fue, junto a las ilustraciones que acompañaban la sección "lectura recreativa", lo que más se incrementó en los almanaques de los últimos veinte años del siglo XIX, transformándose en una constante encontrarnos con imágenes alusivas a los textos literarios publicados. Este es el caso del Almanaque Pintoresco Divertido para el año 1881. Según se observa en la figura 11, la parte escrita del artículo ya no se expone en un solo cuerpo, sino que se utilizan las columnas, lo cual despeja la vista para el lector. Este aspecto ya da cuenta de una lectura que no es intensiva (como lo proponían los demás periódicos del siglo XIX que eran verdaderas enciclopedias y

11 Ambas esquinas inferiores de los grabados de este almanaque están firmadas. El nombre que aparece en la derecha de este corresponde al del dibujante, mientras que el de la izquierda es de quien hizo el grabado.

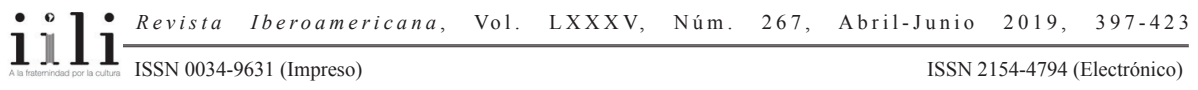


para cuya lectura se requería una concentración especial), sino que ahora es extensiva, lo cual va de la mano con los tiempos más acelerados y, como dice el título, en captar a "todos los gustos", tanto a quien es un asiduo lector como a otro incipiente. En este sentido, los almanaques fueron agentes democratizadores de las prácticas de lectura y también de las prácticas sociales y de costumbres, pues según se observa en el recuadro costumbrista que acompaña al artículo, quienes están comprando en la tienda de géneros son mujeres, lo cual nos habla de un nuevo mercado: las consumidoras.

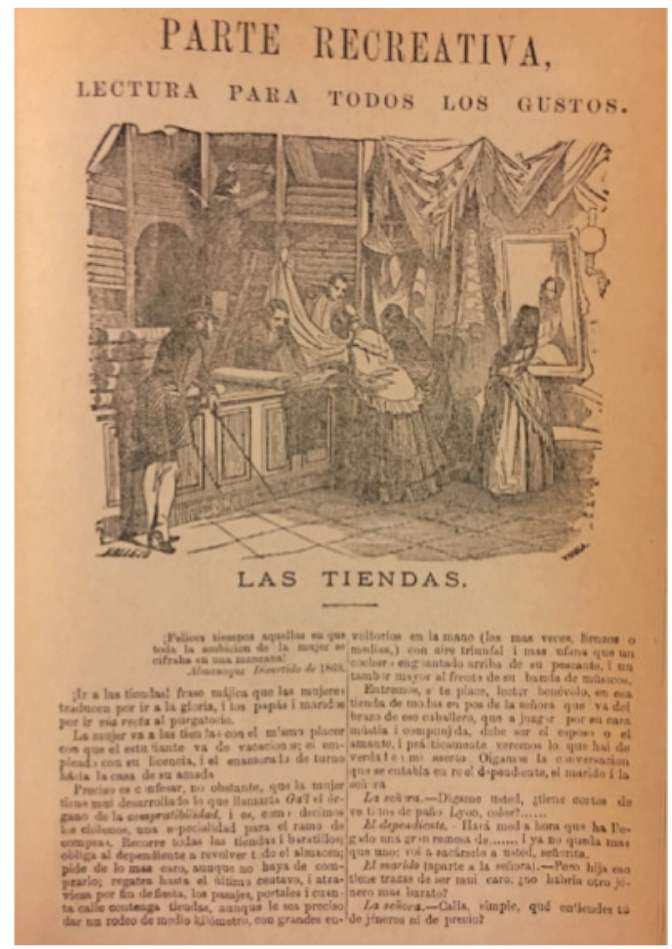

Figura 11: Almanaque Pintoresco Divertido, 1881. El cuadro de costumbres de la imagen está firmada por el grabador "Vallejo", quien era José Vallejo y Galeazo (1821-1882), artista español fundador de la Escuela de Artes y Oficios en Madrid. En cuanto al dibujante (aparecido en la esquina inferior derecha), el firmante es "Varela", sobre el cual no pudimos encontrar noticias.

Los almanaques no desaparecieron en el siglo XX, ya que, según constata Manuel Loyola, estos textos siguieron formando parte del entramado de textos que se publicaban en Chile anualmente. Sin embargo, y de acuerdo a nuestra constatación, los almanaques ya no cumplieron el mismo rol informativo y entretenedor, o, de

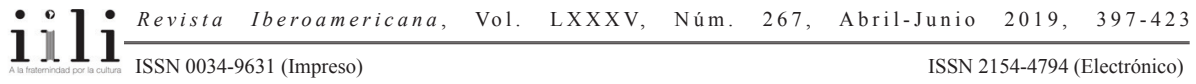


uso y goce, o, si se quiere, magazinesco, pues quienes tomaron ese lugar fueron los magazines, puntualmente Zig Zag, por lo cual los almanaques re-tomaron un espacio, mayoritariamente de utilidad y servicio.

Zig Zag, el "Semanario Ilustrado", apareció el 19 de febrero del año 1905 y fue anunciado amplia y fastuosamente en el país. Estuvo bajo la dirección de Joaquín Díaz Garcés (Ángel Pino), quien desde el periódico El Chileno en 1883, junto a Carlos Silva Vildósola, permaneció activamente ligado a la prensa. Fue además, propietario y director de Instantáneas y la cabeza de El Mercurio. Desde este último medio escrito, Garcés, por petición de Edwards Mac Clure tomó la máxima responsabilidad del magazine.

El semanario destacó desde su primer número por las coloridas imágenes y la incorporación de fotografías en sus páginas, lo cual significó una verdadera revolución para los lectores. De hecho, esta revista estaba pensada íntegramente en resaltar los elementos visuales, cuestión que se manifestó desde la elección del título en adelante, el cual los mismos productores del magazine explicaron:

\section{El PORQUe DEL NOMBRE DE ZIG-ZAG}

Hubo ya de buscarse un nombre para la nueva publicación, y al reunirse el señor Edwards con sus acostumbrados colaboradores, cada uno de ellos exhibió una lista de posibles denominaciones de la nueva publicación. Hubo consenso estimar que ninguno de los nombres escogidos era digno de la pila bautismal de la nueva revista; faltaba a unos novedad; a otros concisión; a aquéllos, belleza; a éstos, sonoridad.

Nadie había pensado en semejante dificultad, y en la reunión hubo un instante de suspenso. De pronto, rompió el silencio el señor Edwards.

-Necesitamos - dijo- un nombre que pueda vocearse con rapidez, que denote agilidad, dinamismo y quede en la mente de quien lo escuche.

Y junto con decir estas palabras, la mano del señor Edwards rubricaba en el aire un movimiento rápido.

-iQué curioso! -dijo uno de los presentes--. ¡Su mano, señor, ha trazado el zigzag de un relámpago!

-¡Zigzag! -exclamó don Agustín-. ¡No busquemos más amigos míos! Hemos encontrado el nombre que hacía falta. "Zig- Zag" se llamará nuestra revista.

Hubo consenso unánime en que el de "Zig-Zag" era el título que reunía las condiciones requeridas. Conciso, original, vibrante. Era un nombre destinado a sobrevivir. (López 68)

El título de la revista no intentó responder a una necesidad por identificar el tema que iba a tratar ni al público al cual se dirigiría; sino que su valor recayó en la fuerza performativa que los productores querían transmitir. 

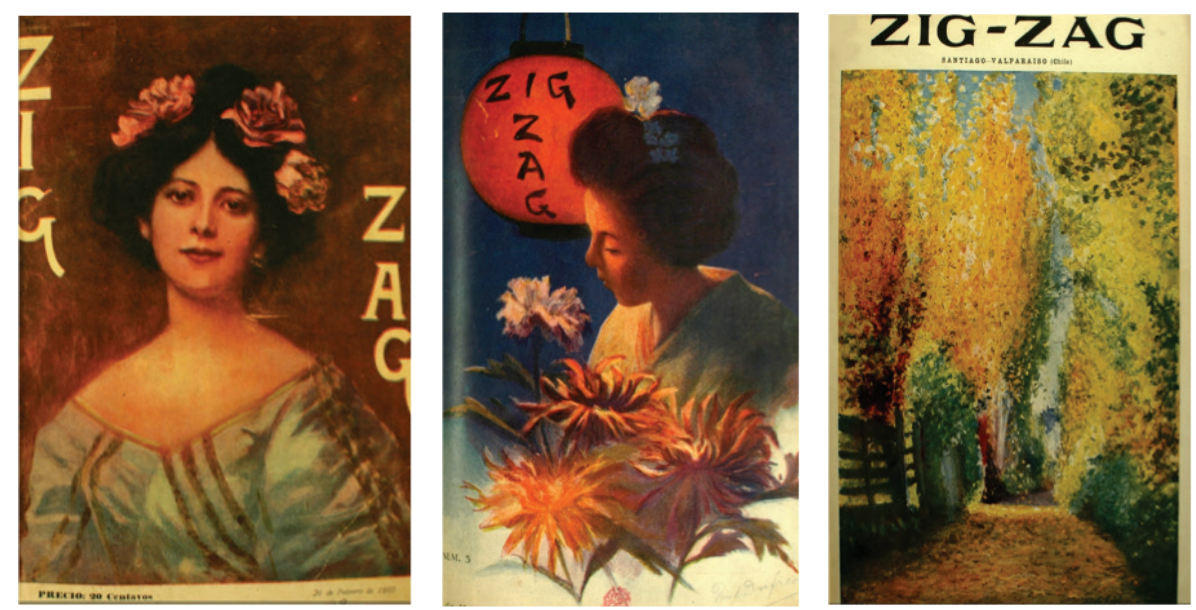

Figura 12a, 12b, 12c: En este sentido, las condiciones que Zig Zag reunió fueron: el incremento del poder, pues la autolegitimación de esta revista no pasó sólo por el engranaje publicitario desplegado, sino que por su nombre, el que cumplía con características clave para el logro del éxito pues era reproducible fácilmente y adaptable a cualquier tipo de letra, forma y tamaño de página para la portada (según se observa en estas imágenes, la de la izquierda y el medio de 1905, y la última de la derecha de 1906); y que por ser un título breve se podría memorizar fácilmente, por ende también sería accesible tanto para los compradores como para los suplementeros, quienes lo anunciarían a viva voz.

Sobre el programa de esta revista, en el primer número fue presentado un breve editorial titulado "Cuatro palabras sobre 'Zig-Zag",

Al presentarse hoy el primer número de Zig-Zag, abrigamos la esperanza de que nuestros lectores benévolamente excusarán algunas omisiones del programa que nosotros mismos hemos querido trazarnos de acuerdo con las necesidades del público. Día a día, el vasto y complicado engranaje de esta revista ilustrada irá suavizandose y puliéndose, hasta que en tiempo muy cercano llegue a ser nuestra publicación lo que deseamos que sea; es decir, un completo órgano de la ilustración, del arte y de la vida del país. [...] Creemos inoficioso decir que siempre serán bien venidas todas aquellas observaciones de nuestros lectores [...].

Mediante un arreglo especial, ajustado con las principales empresas de actualidad fotográficas de Europa y Estados Unidos, entre las cuales se destaca la célebre Underwood \& Underwood de Nueva York [...]. (Zig-Zag, 19 de febrero de 1905, 2)

Zig-Zag se encarga de aclarar, en al menos dos ocasiones, que las decisiones que se consideraron para organizar la publicación tuvieron su origen en los gustos y necesidades de los lectores; es por esto que la falacia a partir de la cual se estructura este argumento es la elusión de responsabilidad por parte del sujeto que enuncia, pues

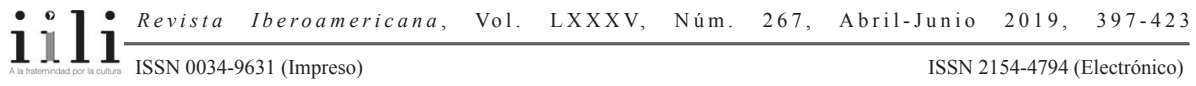


responsabiliza a los consumidores y sus gustos, y no a los intereses de los mismos productores de la revista. Este es el relato de la prensa moderna inaugurada por este magazine, donde los cambios en las revistas, las inclusiones o exclusiones de ciertos escritores y escritores, entre otras medidas, corren, aparentemente, por cuenta de los lectores-consumidores, es decir, responde al dicho popular "el cliente tiene la razón".

De acuerdo con el contexto de satisfacer las necesidades de los lectores, es que Zig-Zag se hizo cargo de cuestiones otrora cubiertas por los almanaques, pero desde dos perspectivas, una estetizada y otra utilitaria. El caso de la primera lo podemos corroborar en la organización temática del semanario, la cual dependía de la fecha que estuviera próxima a conmemorarse. Desde la portada, la publicidad, los artículos, columnas y sección literarias, absolutamente todos ellos estaban en función de recordar la festividad que se celebrara, la cual podía ser religiosa o histórica. El primer caso lo ejemplificamos con los números de 1908 y 1914, respectivamente, ambos alusivos a Semana Santa (figuras 13 y 14). El segundo caso es posible observarlo en la figura 15, la cual celebra y alude al día de la Independencia de Estados Unidos; es decir, es importante señalar que no solo se conmemoraban fechas de Chile, sino también de otras latitudes, pues podemos encontrar números que recordaban la Revolución francesa o el día de la independencia de los demás países de Latinoamérica.

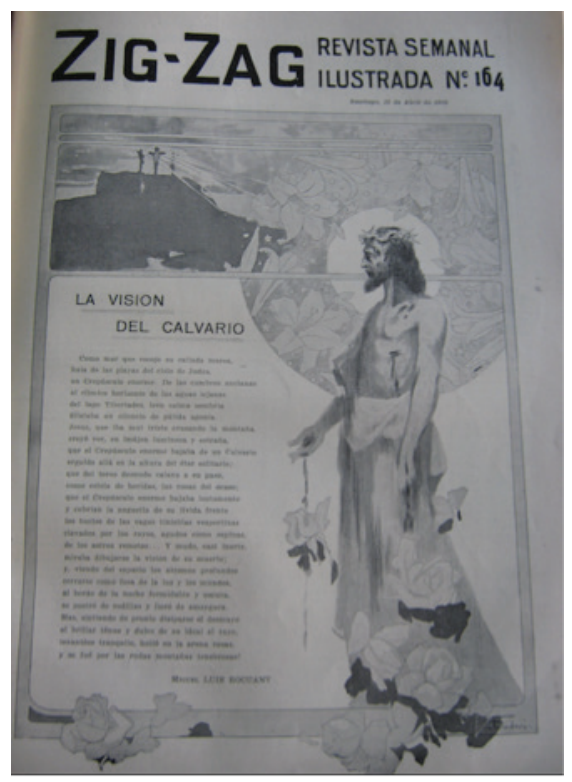

Figura 13: Zig-Zag nº 164, 12 de abril de 1908.

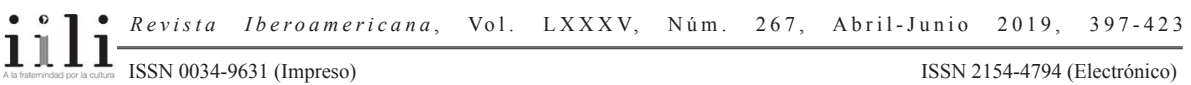




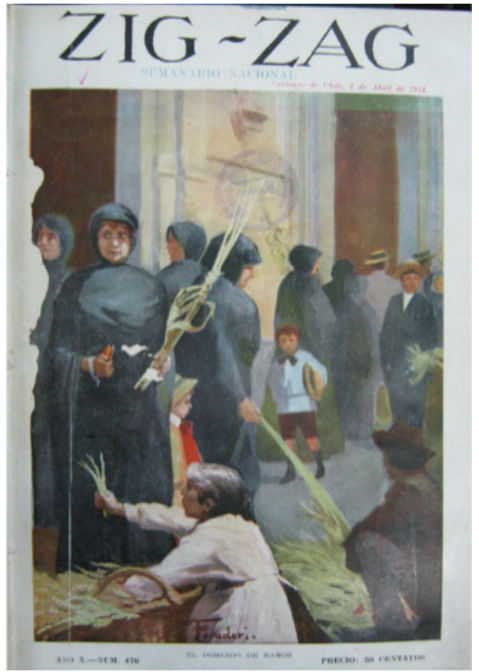

Figura 14: Zig-Zag n ${ }^{\circ} 476,4$ de abril de 1914: en esta imagen se representa un cuadro típico de Domingo de Ramos, en donde se observa a mujeres a la entrada de la iglesia comprando ramos que conmemoran la entrada triunfante de Jesús a Jerusalén, justo una semana antes de ser crucificado.

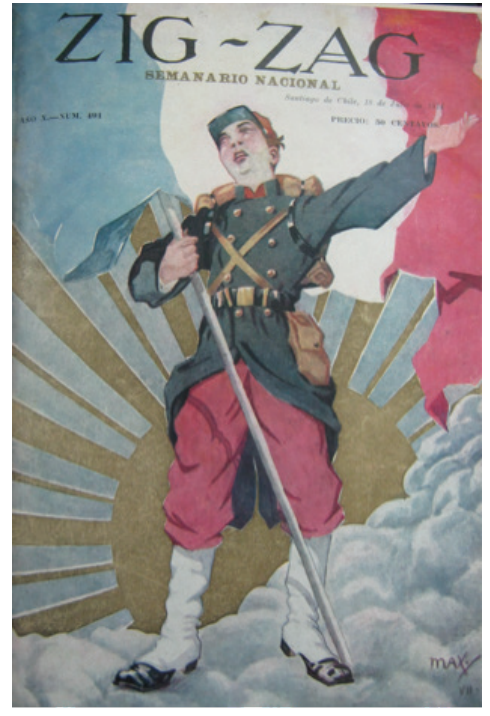

Figura 15: Zig-Zag n ${ }^{\circ} 491,18$ de julio de 1914.

El orden religioso-católico e histórico que organizó temáticamente este magazine, particularmente lo primero, nos lleva a remitirnos al origen y sentido de los almanaques, los que, pese a su sucesiva secularización continuaron incluyendo en la sección de efemérides a festividades religiosas, onomásticos y fiestas nacionales. No obstante lo anterior, lo que demuestra con mayor claridad la voluntad por abarcar sin duda al formato almanaque y al público que año a año los esperaba, lo observamos en dos manifestaciones clave. Primero, de acuerdo con la figura 16, Zig-Zag produjo su propio almanaque, el cual se incluiría como suplemento del magazine ya influenciado por dicho periódico anual; segundo, no conforme con el almanaque propio, el magazine incluía en sus primeras doce páginas del primer número del año un resumen de festividades acompañadas por una imagen representativa de ese mes, según observamos en la figura 17. 


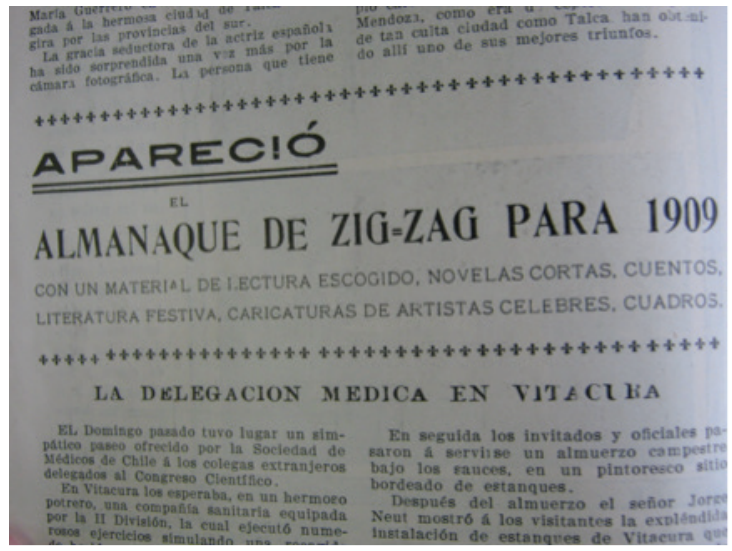

Figura 16: Zig-Zag, 2 de enero de 1909.
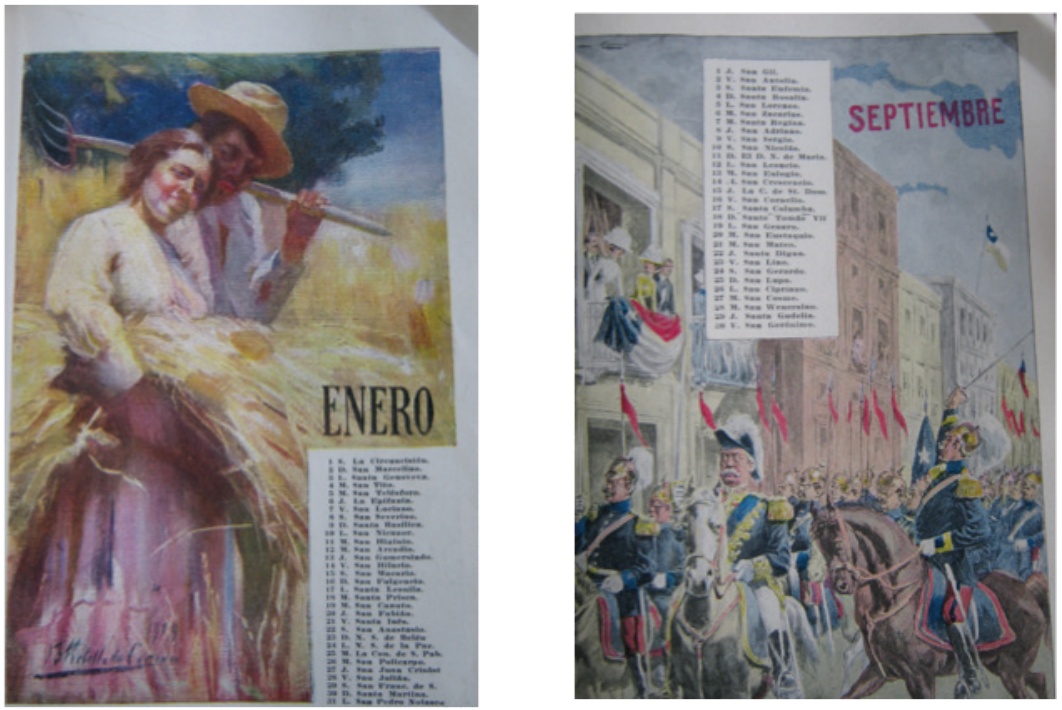

Figura 17a, 17b: Zig-Zag 1 de enero de 1910. La imagen de enero representa la época de la cosecha, en tanto que la de septiembre alude a la marcha que se realiza todos los 19 de septiembre en Chile en honor de las Glorias del Ejército con ocasión de las fiestas patrias.

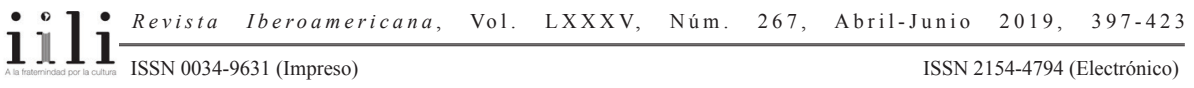




\section{Conclusiones}

A partir de la revisión que hemos realizado en este trabajo, podemos concluir que las ilustraciones son el eje clave que conecta a los almanaques con los magazines, lo que nos permite reconocer una continuidad entre ambos tipos de periódicos, ya que esta novedosa inclusión demuestra los cambios y nuevo espesor sígnico-discursivo que experimentó la prensa desde la segunda mitad del siglo XIX en adelante en Chile. Conforme indicamos al inicio del artículo, fue, precisamente, la constatación de las imágenes en los almanaques decimonónicos y la nueva disposición que los textos, del cual eran complemento las imágenes, sufrieron debido a esta novedosa incorporación, que establecimos el vínculo entre los dos tipos de periódicos de los que nos ocupamos.

Además de corroborar el nexo entre el almanaque y el magazine mediante las similitudes que pusimos en evidencia a lo largo de este texto a través de sus respectivas imágenes, fue de gran ayuda rastrear el origen de estas ilustraciones siguiendo las firmas que en ellas figuraban, las cuales correspondían a dibujantes y grabadores franceses, en su mayoría, y a un español, que habían formado parte de magazines europeos. Esta constatación fue fundamental para este artículo, ya que con ello corroboramos que los almanaques fueron agentes fundamentales para el proceso de modernización de la prensa debido a que se apropiaron de un formato novedoso para Latinoamérica pero probadamente exitoso y encantador de públicos en Europa. Se suma a lo anterior que pudimos corroborar otra de nuestras premisas, la cual señalaba que los almanaques fueron iniciadores del formato magazinesco en la prensa local, y que, por ende, este nuevo estilo de revistas no llegó al país recién en el siglo XX, como habitualmente se afirma.

Por otro lado, constatamos que la práctica lectora más cercana a la entretención que a la adquisición de conocimientos "puros", junto a la democratización de los contenidos y a la puesta en escena de estos de un modo más amable, comenzó en el panorama de la prensa y lectores chilenos con los almanaques, ya que, los demás periódicos que se publicaban por esos mismos años en el país tendían más bien a una especialización que a una inclusión.

En cuanto a las proyecciones de este trabajo, proponemos como vía de estudio la revisión de las diferencias entre la propuesta magazinesca de los almanaques y la de los propios magazines del siglo XIX. Como adelanto de aquello, es posible señalar que pese a que los almanaques revisados, puntualmente los de 1850 en adelante, tuvieron una fuerte preocupación por el desarrollo y la integración de los temas literarios, es bien cierto que estas publicaciones intentan atraer al público que los prefiere por la vía de la entretención y la distracción, por ende, la concepción que se tiene sobre los quehaceres literarios, así como la dedicación y concentración exhaustiva han sido desplazadas por el pasatiempo. Como varios autores lo señalan (Ossandón y Santa Cruz entre los

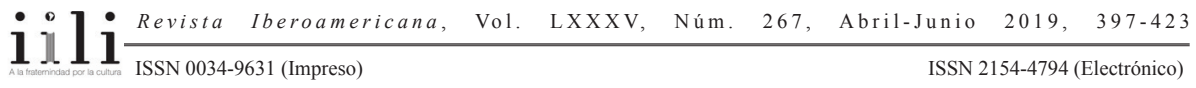


principales), la práctica de lectura ha sufrido un cambio, desde un ejercicio serio hacia el (h)ojeo. Por otro lado, los almanaques estudiados son cercanos al texto-collage, pues se reapropiaron de un modelo central y uniforme, como lo eran los almanaques católicos, secularizándolos y transformándolos en lecturas informativas y divertidas, cercanas en formato a lo que posteriormente entenderemos por magazine.

En cuanto a la apropiación de las funciones clásicas de los magazines en los cuales se inspiraron los almanaques, la principal diferencia con dichos periódicos que se popularizaron en Chile como tales a partir del siglo XX, es que éstos eran proyectivos, es decir, proponían imágenes de futuro y del modo en que la ciudad y todas sus prácticas debieran constituirse para abrazar la modernidad. Por otro lado, la justificación de la inclusión de los contenidos no estaba fundamentada en la opinión pública (espacio que recién se conformaba en el siglo XIX) o en los deseos de los lectores, sino que en las disposiciones que los productores tras los almanaques tuviesen respecto de la constitución de esta joven nación. La imagen, por su parte, es utilizada en el siglo XIX en los almanaques para acercar hacia el lector el resultado final de algo que está por venir, por lo tanto, por medio de ellas los responsables de estos periódicos se aseguraban que alfabetos y analfabetos comprendieran el mensaje.

Sobre las apropiaciones que Zig Zag efectuó respecto del formato almanaque, el aspecto más destacable es que dicho magazine justificaba todas sus acciones a favor de la opinión pública, a la cual apela en sus diversos textos programáticos como editoriales y prospectos. Por lo tanto, es posible desprender de esto que los almanaques fueron periódicos altamente esperados y consumidos, pese a su periodicidad, razón suficiente para que esta empresa editorial pusiera sus ojos en dicho formato y lo absorbiera, para así ofrecer a sus lectores la opción ya no de tener esta clase de periódico, ordenador, informativo, entretenido y vistoso, solo una vez al año, sino que ahora todas las semanas. 
BiBLIOGRAFíA

\section{Periódicos:}

Almanaque Chileno [Santiago, Chile]. 1855.

Almanaque Divertido [Santiago, Chile]. 1879.

Almanaque Enciclopédico Pintoresco [Santiago, Chile]. 1860.

Almanaque Pintoresco Divertido [Santiago, Chile]. 1881.

Almanaque Pintoresco e Instructivo [Santiago, Chile]. 1851.

Almanaque Pintoresco e Instructivo [Santiago, Chile]. 1852.

El Cóndor [Santiago, Chile]. Año 1. nº 1. 1863.

El Correo Literario [Santiago, Chile]. Año 1. nº 1. 1858.

Journal Pour Tous [París, Francia]. 11 de julio de 1857.

Medio siglo de Zig-Zag, [Santiago, Chile]. 1954.

Zig-Zag [Santiago, Chile]. No 1, 19 de febrero 1905.

Zig-Zag n ${ }^{\circ} 164$ [Santiago, Chile]. 12 de abril 1908.

Zig-Zag no 476 [Santiago, Chile]. 4 de abril 1914.

Zig-Zag no 491 [Santiago, Chile]. 18 de julio 1914.

\section{Bibliografía referenciada:}

Alvarado, Marina. "Revistas culturales y literarias chilenas 1894-1920: instancias legitimadoras para la autonomización del campo literario nacional". Tesis de doctorado, Pontificia Universidad Católica de Valparaíso, 2010.

Burke, Peter. Visto y no visto. El uso de la imagen como documento histórico. Barcelona: Biblioteca de Bolsillo, 2005.

Chartier, Roger. El mundo como representación. Estudios sobre historia cultural. Barcelona: Gedisa, 2005.

Fernández Bravo, Álvaro. "La frontera portátil: Nación y temporalidad en Lastarria y Sarmiento". Revista Iberoamericana LXIII/178-179 (1997): 141-47.

López, Félix. "Nuestra propia historia". Medio siglo de Zig-Zag, número especial (1955): 64-79.

Loyola, Manuel. "Los almanaques y la construcción de sentido de la modernidad chilena”. Revista Mapocho 71 (2012): 243-59.

Ossandón, Carlos. El crepúsculo de los sabios y la irrupción de los publicistas. Santiago, Chile: Lom, 1998.

Ossandón, Carlos y Eduardo Santa Cruz. El estallido de las formas. Chile en los albores de la cultura de masas. Santiago, Chile: Lom, 2005.

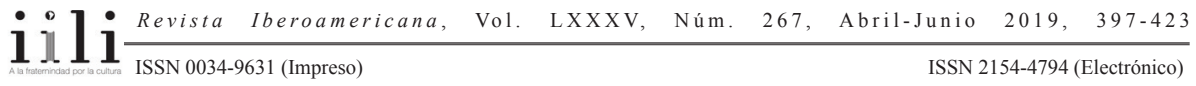


Entre las alas y el plomo. Gestación de la prensa moderna en Chile. Santiago, Chile: Lom, 2001.

Pas, Hernán. "La seducción de las imágenes. El ingreso de la litografía y los nuevos modos de publicidad en Latinoamérica". Caracol 2 (2011): 10-41.

Poblete, Juan. Literatura chilena del siglo XIX: entre públicos lectores y figuras autoriales. Santiago, Chile: Editorial Cuarto Propio, 2002.

Román, Claudia. "De la sátira impresa a la prensa satírica. Hojas sueltas y periódicas en la configuración de un imaginario político para el Río de la Plata (1779-1883)". Estudios 18-36 (2010): 324-49.

Santa Cruz, Eduardo. "Modernización y cultura de masas en el Chile de principios de siglo XX: el origen del género magazine”. Comunicación y Medios 13 (2002): 169-84.

Subercaseaux, Bernardo. Historia del libro en Chile (alma y cuerpo). Santiago, Chile: Lom, 2000.

Szir, Sandra M. "De la cultura impresa a la cultura de lo visible. Las publicaciones periódicas ilustradas en Buenos Aires en el siglo XIX”. Nervaduras de la esfera pública: revistas, periódicos y discusiones, 2007. 11 Nov. 2015.

Palabras clave: almanaque, ilustraciones, Zig-Zag, laiazación

Recibido: $\quad$ junio 2016

Aprobado: $\quad$ septiembre 2018

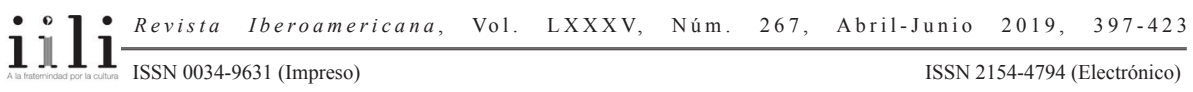


